\title{
Editor's Note: A Message of Thanks
}

\author{
Libby Balter Blume ${ }^{1}$
}

Michigan Family Review (MFR) is a peer-reviewed interdisciplinary publication of MiCFR focused on professional application and scholarly inquiry. The main purpose of the Review is to publish articles and reviews about critical contemporary problems confronting families and those who provide service to them. Articles are intended to be succinct statements of issues, research findings, theoretical ideas, policies, or program recommendations that will be useful in practice. Each issue focuses on a single theme and provides a forum for a wide range of professionals and others interested in strengthening family life. Readers and contributors include educators at many levels in several fields, social service staff, researchers, attorneys, medical and health personnel, clergy, and public policy makers, as well as practitioners in community and citizen-action groups, and family members themselves.

With this issue of Michigan Family Review, we celebrate the tenth anniversary of the journal, and I complete my term as its founding co-editor. I want to thank many individuals for their support of the journal over the past ten years. Since it was begun by a small group of interested members of the Michigan Council on Family Relations (MiCFR) in 1996, the journal has achieved wide distribution as an open-access journal through The University of Michigan Libraries thanks to Maria Bonn, Director of the Scholarly Publishing Office, and the technical assistance of Brian Lee. The journal web page describes our mission, editorial review board, and manuscript submission requirements: http://www.hti.umich.edu/m/mfr/about.html.

The original creative group from MiCFR included myself, Anne Soderman (MSU) who also served a term as co-editor, Linda Dannison (WMU), Jeanne Brown (former MiCFR Executive Director), and Mary Ann Larzelere (former staff member of People's Church in East Lansing where our earliest

1 Libby Balter Blume, Ph.D., CFLE is Professor, Department of Psychology, Women's Studies, \& Community Development, University of Detroit Mercy, 4000 West McNichols Rd., Detroit, MI, 48221-3038. Electronic mail may be sent via the Internet to blumelb@udmercy.edu 
meetings were held). Founding co-editor Margaret (Peg) Bubolz, Professor Emerita of Family and Child Ecology at Michigan State University, deserves ongoing credit for writing the editorial policies and author guidelines we still use today with only minor modifications for on-line submissions. I also must thank the talented graphic designers at Media Graphics in Williamston for the initial design of the journal and its ampersand logo and the National Council on Family Relations for permission to use their registered trademark.

The success of Michigan Family Review is due in large part to the dedication of our first Editorial Advisory Board whose members were invited because they represented institutions across the state as well as the interdisciplinarity so necessary to scholarship in the field of family studies: Thomas Eveland (Chief Judge, Eaton County Courts), Roy Gerard (Family Medicine, MSU), Alan Hovestadt (Counselor Education, WMU), Bob Lee (formerly Marriage \& Family Therapy, MSU), Edith Lewis (Social Work, UMAnn Arbor), the late Elizabeth Olsen (formerly Institute of Gerontology, WSU), Mary Periard (Nursing, UM-Flint), Carl Taylor (Institute for Children, Youth \& Families, MSU), Anne Soderman (Child \& Family Ecology, MSU), Glenn Weisfeld (Psychology, WSU), and Elizabeth Williams (formerly Psychology, Mercy College of Detroit).

For the past four years, invited guest editors have enriched the journal immeasurably. I thank Carla Groh (Health Professions, UDM) for the excellent issue on Families \& Health Care, Gloria Warren (formerly Teacher Education, Marygrove College) for the provocative issue on Faith \& Families, Edie Lewis (Social Work, U of M) for the inaugural electronic issue on Families \& Practice, and current co-guest editors Maxine Baca Zinn (Sociology, MSU) and Heather Dillaway (Sociology, WSU) for this superb issue on Feminism \& Family Life. Lastly, I leave the journal in the capable hands of incoming editor Martin Covey (Family Life Education, Spring Arbor University). Marty's first issue is on Families \& Technology and will be guest-edited by Bruce Covey (Creative Family Concepts, LLC). We invite you to submit articles or book reviews to mcovey@arbor.edu and hope that the journal will continue to be a stimulating and useful resource for many years to come.

Libby Balter Blume

University of Detroit Mercy

Detroit, Michigan 